\title{
Razlike v zaznavanju bivalnega okolja glede na starost prebivalcev
}

Zanimalo nas je, ali lahko morebitne statistično značilne razlike glede na demografske značilnosti udeležencev kažejo na medgeneracijsko različna dojemanja bivalnega okolja. Za proučevanje smo uporabili metodologijo, ki sloni na kvantitativni metodi. Starejši udeleženci raziskave so poročali o večjem zadovoljstvu, večjem občutku družbeno-ekonomske homogenosti soseske, boljših sosedskih odnosih in boljših občutkih glede vzdrževanja grajenega okolja kot mlajši udeleženci. Zanimivo pa je, da mlajši udeleženci raziskave izražajo višjo stopnjo strinjanja glede vandalizma ter fizičnih in besednih napadov v soseski. Rezultati raziskave so bili v nasprotju s pričakovanji, saj predhodne študije pri starejših prebivalcih v primerjavi z mlajšimi ugotavljajo precej nižje stopnje strinjanja glede zadovoljstva z grajenim okoljem in pomembno višje sto- pnje glede kriminalitete. Rezultate si razlagamo z ugotovitvami številnih raziskovalcev, skladno s katerimi starejši ljudje še vedno na splošno raje ostarijo v svojem domu, v znanem okolju, saj se pogosto bojijo, da bi zanje prehod v kolektivno ali institucionalno življenjsko okolje neizogibno pomenil izgubo neodvisnosti, kar posledično pomeni, da okolje sprejemajo tako, kot je. V raziskavi ugotavljamo še, da vrsta izkazanih statistično značilnih razlik kaže na to, da bivalno okolje, ki ima velik učinek na zadovoljstvo in dobro počutje, vendarle ne nudi enake kakovosti grajene socialne infrastrukture prav vsem uporabnikom, ki se ločijo po demografskih razlikah.

Ključne besede: socialna infrastruktura, grajeno okolje, demografske značilnosti, starejši, Slovenija 


\section{Uvod}

Kakovost življenja, ki je danes v svetu eden prevladujočih konceptov, je le stežka doumljiva brez kakovosti urbanega okolja, za katero pa je čedalje bolj značilno, da se oblikuje humano in naravnano k človeku (Temeljotov Salaj in Petrič, 2009). Kakovost urbanega okolja razumemo kot povezano celoto, ki zajema socialno dojemanje tega (npr. soseske) in kakovost grajenega bivalnega okolja. Ta naj bi zadovoljevala vse uporabnike. Adriaansova (2007) navaja, da so poglavitne spremenljivke, ki ustvarjajo kakovost urbanega okolja, tri: starost uporabnikov takega okolja, značilnosti bivalne skupnosti in dejanske značilnosti grajenega okolja. Prav zato nas je v raziskavi zanimalo, ali se kažejo statistično značilne razlike glede na starost udeležencev raziskave glede zaznavanja značilnosti bivalne skupnosti (splošno zadovoljstvo, družbeno-ekonomska homogenost, medsosedski odnosi, stopnja kriminalitete, občutek strahu in nelagodja, medsosedska pomoč) in glede na grajeno okolje (razvitost grajenega okolja, vzdrževanje in čistoča). Zanimalo nas je, ali se med udeleženci raziskave pojavljajo statistično značilne razlike, ki lahko kažejo na medgeneracijsko pomembna različna dojemanja bivalnega okolja ali, gledano širše, dojemanja grajene socialne infrastrukture, v kateri živijo.

Stopnja razvitosti kraja vpliva na stopnjo zadovoljstva uporabnikov in stopnjo zadovoljevanja njihovih potreb (Missimer idr., 2017; Sierra idr., 2017, 2018). Številni avtorji, kot so Baumeister in Leary (1995) ter Engle in Altschuld (2014), so poudarili, da je treba upoštevati predvsem potrebe, te morajo $\mathrm{v}$ vseh razmerah delovati na način razmišljanja, čustva in vedenje. Če potrebe niso izpolnjene, je treba upoštevati negativne posledice take neizpolnitve. Kadar potrebe niso izpolnjene, bi se moral njihov objektivni pomen povečati ali zmanjšati. Avtorji so opozorili še, da je treba posebno pozornost nameniti potrebam, ki so skupne vsem. Kulbickienè (2004) meni, da potrebe izražajo usmeritve in izbire uporabnikov. Analiza potreb $\mathrm{v}$ zvezi s socialno infrastrukturo je zato razumljena kot ocena povpraševanja po storitvah in objektih (Weber idr., 2016). Opredelitev potreb je postopek opisovanja problemov ciljne populacije in možnih rešitev teh težav (Vaznoniené in Pakeltiené, 2017). Analiza potreb se zato osredotoča na prihodnost, tj. na to, kaj je treba storiti, in ne na to, kar je bilo storjeno (Vaznonienè in Pakeltiené, 2017).

V članku razumemo grajeno socialno infrastrukturo kot strukturo, ki je zgrajena na podlagi navedenih potreb uporabnikov, njena uporabnost pa se meri z ravnjo zadovoljstva ali dobrega počutja teh uporabnikov. Grajena socialna infrastruktura je eden od prevladujočih dejavnikov, ki zagotavlja zadovoljevanje osnovnih človeških potreb (Frolova idr., 2016). Če socialna infrastruktura ustreza potrebam in pričakovanjem prebivalcev, to pomeni večjo kakovost njihovega življenja. Če pa potreb prebivalcev ne zadovoljuje ali ne omogoča izbire, se pojarljajo posebna socialna in gospodarska vprašanja, ki vplivajo na dobro počutje prebivalcev (Vaznoniené, 2015). Dobro počutje kaže na kakovost življenja. Študij, s katerimi bi želeli ugotoviti razmerja med dejavniki blaginje prebivalstva in stopnjo razvoja družbene infrastrukture v skupnosti, ni veliko. Eno podobnih študij je opravil Popov (2017): raziskoval je razmerja med prometno infrastrukturo in kazalniki dobrega počutja, in to s korelacijsko analizo na podlagi podatkov latvijskega statističnega urada. Njegova raziskava odpira široko področje za nadaljnje proučevanje ter vprašanja in probleme za nadaljnje podrobnejše analize ter nas je spodbudila $\mathrm{k}$ podrobnejši analizi posameznih dejavnikov v soseski, tj. kako jih uporabniki dojemajo, in grajenega okolja glede na osnovne demografske značilnosti udeležencev. Kot vhodni demografski dejavnik raziskave ločimo tri starostne skupine udeležencev raziskave: udeleženci, stari do 35 let, spadajo v mlajšo generacijo, udeleženci, stari od 35 do 65 let, spadajo v srednjo generacijo, udeleženci, starejši od 65 let, pa spadajo v starejšo generacijo. Pri tem sledimo delitvi, ki jo navaja Miloševič Arnoldova (2003). V naši študiji obravnavamo starejše kot enotno skupino, tj. osebe, starejše od 65 let. To starostno mejo postavlja tudi Statistični urad Slovenije.

\section{Zaznavanje grajenega okolja}

Erdogan in sodelavci (2008) poudarjajo, da na splošno zadovoljstvo $z$ nastanitvijo neposredno vplivajo zaznane življenjske razmere, te pa so povezane $\mathrm{z}$ zadovoljstvom $\mathrm{z}$ dejanskim okoljem, z družbenimi odnosi, z delovanjem lokalnih oblasti in zaznano kakovostjo okolja in objektov. Mnenja prebivalcev o njihovi soseski ponujajo pomembne vpoglede $\mathrm{v}$ to problematiko. Kot navaja Adriaansova (2007), ta mnenja osvetlijo, kateri vidiki imajo večji učinek na splošno zadovoljstvo glede bivalnega okolja. Stanovanjska okolja lahko delno proučujemo z objektivnimi merili, kot so obdobje gradnje, arhitekturni slog, prostorska struktura, količina zelenih površin in geografska lega. V zvezi z ugotovitvami o zadovoljstvu v soseskah sta Sirgy in Cornwellova (2002) značilnosti sosesk, ki vplivajo na zadovoljstvo, razvrstila v dejanske značilnosti (npr. vzdrževanje domov in dvorišč, urejanje okolice in ulična razsvetljava, preobremenjenost $s$ hrupom in raven hrupa, dostop do objektov in kakovost okolja), socialne značilnosti (interakcije $s$ sosedi, povezanost skupnosti, prostor za igro na prostem, stopnja kriminalitete, občutek zasebnosti doma) in gospodarske značilnosti (vrednost stanovanja v soseski, življenjski stroški, socialno-ekonomski status soseske in nadstandard ali izboljšave soseske). Tudi številni drugi raziskovalci ugotavljajo, da na stanovanjsko zadovoljstvo vplivajo zelo raznovrstne objektivno in subjektivno zaznane razmere (Theodori, 2001; Grum in Temel- 
jotov Salaj, 2013; Grum in Kobal Grum, 2015). Urbanisti velik pomen namenjajo socialnim vprašanjem in kakovosti življenja, kar kaže na to, da je stanovanje družbeno vprašanje, ki ne vključuje le njegove konstrukcije in okolja, temveč tudi zadovoljstvo s kakovostjo okolja (Sam idr., 2012). Arhitekti se strinjajo z urbanisti, da to posledično vpliva na kakovost življenja in psihosocialne vidike prebivalcev (Mohit idr., 2010). Raziskovalci zatrjujejo, da je stanovanjsko zadovoljstvo odsev zadovoljstva in radosti v stanovanjskem območju v soseski. To vključuje socialne in sosedske odnose, družbene dejavnosti, objekte za družbene dejavnosti in komunalne storitve (Sam idr., 2012). Poleg zadovoljstva, družbeno-ekonomske homogenosti in socialne stabilnosti soseske je pomemben tudi občutek varnosti, kar številne raziskave povezujejo $s$ stopnjo kriminalitete v okolju (Newmam, 1972, Meško, 2001; Grum, 2017). Kot navaja Meško (2001), naj bi oblikovanje prostora zagotavljalo strukturo, ki odvrača od kriminalitete, torej naj bi zunanje značilnosti okolja temeljile na lastnostih, ki kažejo na to, da je okolje pod nadzorom in kot tako naj bi v ljudeh vzbujalo občutek varnosti. V takem okolju naj bi se spodbujali večja skrb zanj, več stikov s sosedi (dobri medsosedski odnosi) in večja medsosedska pomoč, tudi zadovoljstvo prebivalcev z lastno nepremičnino naj bi bilo večje (Grum, 2017). Newman (1972) te dejavnike združuje v teritorialnost (občutek pripadnosti soseski), naravno nadzorstvo (zaznavanje družbeno-ekonomske homogenosti, prisotnost policije, varnostih služb, gasilcev), zunanjo podobo (vzdrževanje, urejeni parki, parkirišča, sprehajalne poti) in okolje (razvitost grajene socialne infrastrukture).

V zvezi s starostjo udeležencev ugotavljamo, da številne raziskave kažejo, da si starejši želijo čim dlje časa ostati v svojem domu, torej v znanem okolju, in da želijo, kolikor je mogoče, dolgo ohraniti svojo neodvisnost in samostojnost (Rojo idr., 2001; Sabia, 2008; Costa-Font idr., 2009; Wiles idr., 2009). Roy in sodelavci (2018) so ugotovili, da pri starejših na preselitve pomembno vplivajo dejavniki, povezani z grajenim okoljem, in dejavniki, povezani s socialnim, psihološkim, psihosocialnim in prostorsko-časovnim kontekstom. Starejši ljudje še vedno na splošno raje ostarijo v svojem domu (Harper in Bayer, 2000; Greenwald idr., 2003; Secker idr., 2003; Wylde, 2008), pogosto zato, ker se bojijo, da bo prehod v kolektivno ali institucionalno življenjsko okolje neizogibno pomenil izgubo neodvisnosti (Parry idr., 2004; Imamoglu, 2007). Prostor, ki se nanaša na odnose starejših z njihovim življenjskim okoljem kot simbolno predstavitev doma kot neodvisnost (Parry idr., 2004), je lahko temelj za nadaljnjo konceptualno izpopolnitev (Kemp idr., 2012). Vendar številne raziskave kažejo še, da lahko nevzdrževano grajeno okolje prepreči telesno aktivnost med starejšimi (Balfour in Kaplan, 2002; Strath idr., 2007; Mendes de Leon idr., 2009; Gallagher idr., 2010). Zato so starejšim še posebno pomembni specifični vidiki grajenega okolja (Grum, 2017). Številne raziskave kažejo na učinek ne- katerih demografskih dejavnikov, npr. starost prebivalcev, na raven izraženega strahu in na interakcijo med socialno strukturo udeležencev in njihovim doživljanjem strahu (Ferguson in Mindel, 2007). Občutek pripadnosti neki skupnosti lahko ljudem pomaga, da bolj zaupajo svojim sposobnostim, s tem pa se ublaži občutek za nevarnost viktimizacije in se zmanjša strah (Meško idr., 2012). Po drugi strani lahko mlajši udeleženci raziskave grajeno okolje in odnose v njem razumejo drugače. Uršič (2005) je na primeru Savskega naselja v Ljubljani proučeval, ali dejavniki, kot so starost naselja in slabše vzdrževanje in posledično slabšanje bivalne kakovosti naselja, povzročajo selitve neke skupine prebivalstva ter večjo socialno nehomogenost in socialno nestabilnost. Ugotovil je, da se dobra petina stanovalcev namerava v bližnji prihodnosti preseliti in da o tem razmišljajo predvsem prebivalci, stari do 40 let.

Elementi grajenega okolja vplivajo na obnašanje uporabnikov. Če je bivalno okolje urejeno, čisto, vzdrževano, se pričakuje tudi, da bo posamezna stanovanjska stavba ohranjena, $v$ sozvočju s sosesko in v skladu z zadevnim grajenim okoljem. Vendar grajeno okolje običajno vpliva na raven pričakovanega ali zahtevanega vzdrževanja stavbe, saj dobro vzdrževana infrastruktura običajno zahteva dobro vzdrževane nastanitvene zmogljivosti, sicer je podoba soseske neskladna, kar vpliva na počutje uporabnikov (Grum, 2017). Zgoraj navedene ugotovitve so nas vodile pri oblikovanju vprašalnika.

\section{Metodologija}

Raziskovanje, povezano z bivalnimi okoljem, se izvaja že dolgo, kot pa ugotavljajo Smrke, Blenkuš in Sočan (2018), v Sloveniji še ni bil objavljen sistematični pregled vprašalnikov, uporabljenih v podobnih študijah. Kot povzemajo, bi se morali raziskovalci bolj nagibati k uporabi že izdelanih vprašalnikov, strinjajo pa se, da na tem področju raziskovanja ni veliko vprašalnikov s preverjeno veljavnostjo (Smrke idr., 2018). Posledično naša metodologija sloni na kvantitativnem pristopu, na anketnem vprašalniku, ki smo ga oblikovali skladno z izsledki v literaturi Gruma in Temeljotov Salajeve (2011). Raziskovalna vprašanja, ki se porajajo pri raziskovanju kakovosti bivalnega urbanega okolja ali stopnji zadovoljstva uporabnikov in njihovih potreb, danes večinoma slonijo na interdisciplinarnih raziskovalnih pristopih, ki pa že sami po sebi odpirajo nova vprašanja. Odpirajo se neraziskana raziskovalna področja, ki jim kakovostni merski instrumenti ne sledijo vedno. Menimo pa, da nekatere protislovne ugotovitve $\mathrm{v}$ raziskovanju zadovoljstva $\mathrm{z}$ bivalnim okoljem in številna vprašanja, ki ostajajo odprta na področju ocenjevanja, niso posledica le pomanjkljivih metodoloških pristopov. Menimo, da je način merjenja zadovoljstva z bivalnim okoljem $\mathrm{v}$ empiričnih analizah pomemben, predvsem $\mathrm{v}$ nadaljevanju raziskav (kot je naša), ki nakazujejo pomembne 


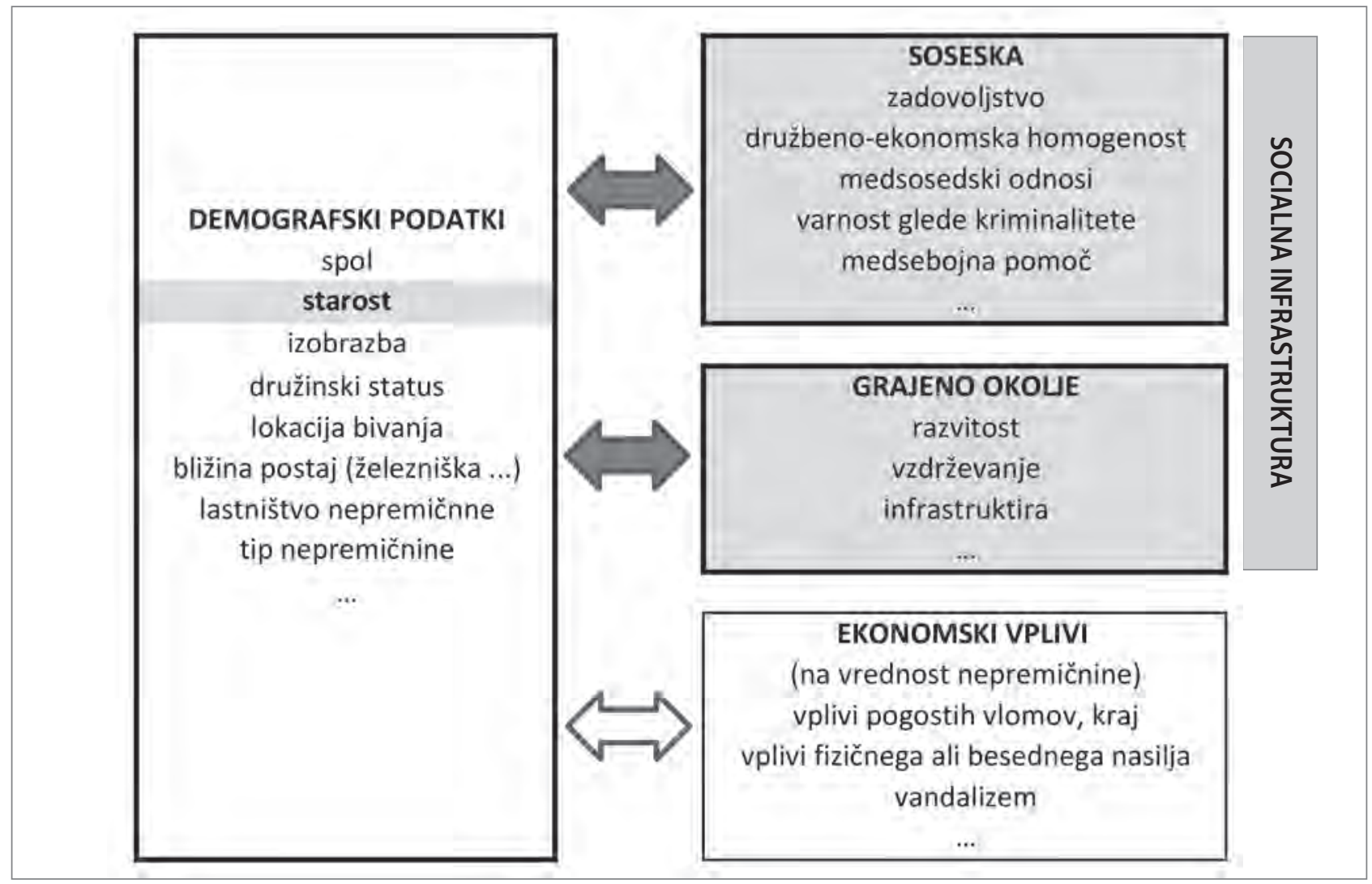

Slika 1: Izločeni faktorji, od katerih nas v nadaljevanju zanima povezava med demografskimi podatki (starost), sosesko in grajenim okoljem (ilustracija: avtor)

odgovore na raziskovalna vprašanja, in sicer, prvič, v smislu odpravljanja morebitnih zgoraj navedenih vplivov na dobljene rezultate in, drugič, $\mathrm{v}$ smislu potrditve ponovljive in preverjene metodologije ali merskih instrumentov.

Spoznavni cilji raziskave so opisni (opis značilnosti in stanja) in pojasnjevalni (ugotovitev in pojasnitev medsebojnih odvisnosti). Osnova za izvedbo raziskave so rezultati analize, opravljene po proučevanju znanstvene literature, podane v prejšnjem poglavju. Raziskavo smo načrtovali v dveh fazah (Grum in Temeljotov Salaj, 2011). V prvi fazi smo načrtovali oblikovanje vprašalnika in ugotavljanje ustreznosti metrijskih elementov vprašalnika. $\mathrm{V}$ ta namen smo izvedli pilotsko raziskavo na ustreznem vzorcu $(\mathrm{N}=55)$. Podatki so bili zbrani s spletnim anketiranjem v letu 2018. Vprašalnik je strukturiran in zaprtega tipa. Podatke smo obdelali s programom SPSS. Udeleženci so na vprašanja odgovarjali z uporabo Likertove lestvice od 1 do 5 , pri čemer vrednost 5 pomeni popolno strinjanje, vrednost 1 pa popolno nestrinjanje. Vprašalnik vsebuje 26 vprašanj. Izvedli smo eksploratorno faktorsko analizo, pri kateri se proučujejo povezave med spremenljivkami, in poskušali najti novo množico spremenljivk (manj kot merjenih spremenljivk), ki pomenijo to, kar je skupnega opazovanim spremenljivkam. $\mathrm{Z}$ rotiranjem smo iskali teoretično pomembne faktorje in čim preprostejšo faktorsko strukturo. V raziskovanju pojmov, ki so ključni, nismo mogli neposredno meriti. Merili smo jih posredno s kazalniki tistega, kar naj bi merili. Skladno z literaturo smo zbrali nekaj neposredno merljivih spremenljivk, ki so kazalniki pojma (konstrukta), ki ga želimo meriti, nato pa smo poskušali razkriti, ali so povezave med izbranimi opazovanimi spremenljivkami pojasnljive s predpostavljeno nemerljivo spremenljivko, ali pa je morda treba postaviti kompleksnejšo strukturo povezanosti. Cilj je ugotoviti, ali so zveze med opazovanimi spremenljivkami pojasnljive $\mathrm{z}$ manjšim številom posredno opazovanih spremenljivk. S faktorsko analizo smo tako izločili štiri faktorje, ki so pojasnili več kot 63,88 odstotka variacije, kar je več, kot je predpisani minimum 60 odstotkov (Bastič, 2006). Faktorji, ki jih je izločila faktorska analiza, se pokrivajo $s$ faktorji, ki smo jih združevali v vprašalniku. $S$ prvim faktorjem so visoko nasičene postavke, ki po vprašalniku spadajo na področje dejavnikov socialne strukture in ki opisujejo značilnosti soseske, kot jo zaznavajo udeleženci (18,15\%) (zadovoljstvo, družbeno-ekonomska homogenost, medsosedski odnosi, varnost glede kriminalitete, medsebojna pomoč ipd.). $\mathrm{Z}$ drugim faktorjem so visoko nasičene postavke, ki po vprašalniku spadajo na področje dejavnikov ekonomskih vplivov na vrednost nepremičnin $(17,07 \%)$ (vplivi pogostih vlomov, fizičnega ali besednega nasilja, vandalizem ipd). $S$ tretjim faktorjem so visoko nasičene postavke, ki po vprašalniku spadajo na področje grajenega okolja (14,97 \%) (razvitost infrastrukture, vzdrže- 
Preglednica 1: Prikaz rezultatov analize variance

\begin{tabular}{|c|c|c|c|c|c|c|}
\hline Spremenljivke & & Vsota kvadratov & df & Srednji kvad. & $\mathrm{F}$ & $\mathrm{p}$ \\
\hline Infrastruktura (policija, gasilci ...) & * & 12,257 & 4 & 3,064 & 2,473 & 0,043 \\
\hline Zadovoljstvo z nepremičnino & & 1,541 & 4 & 0,385 & 0,370 & 0,830 \\
\hline Družbeno-ekonomska homogenost & & 2,949 & 4 & 0,737 & 1,088 & 0,362 \\
\hline Medsosedski odnosi & $*$ & 6,460 & 4 & 1,615 & 2,285 & 0,050 \\
\hline Pogostost kriminalitete & $*$ & 31,301 & 4 & 7,825 & 2,489 & 0,042 \\
\hline Splošni občutek strahu & & 10,121 & 4 & 2,530 & 1,470 & 0,209 \\
\hline Medsebojna pomoč & & 1,421 & 4 & 0,355 & 0,465 & 0,762 \\
\hline Razvitost grajenega okolja & * & 13,393 & 4 & 3,348 & 3,055 & 0,016 \\
\hline Vzdrževanje grajenega okolja & & 4,436 & 4 & 1,109 & 1,402 & 0,232 \\
\hline
\end{tabular}

* Razlika je statistično značilna $(p<0,05)$.

** Razlika je statistično značilna $(p<0,01)$.

*** Razlika je statistično značilna $(p<0,001)$.

vanje ipd.). Faktorska analiza uvršča spremenljivko čistoča soseske kot samostojen faktor (14,67 \%), vendar so zaznane močne korelacije z dejavniki grajenega okolja (npr. negativna korelacija med dobrim vzdrževanjem in slabo čistočo izkazuje vrednost $-0,55)$, zato smo jo teoretično uvrstili v sklop zadnjenavedenih dejavnikov, v nadaljevanju pa tega faktorja nismo obravnavali. Obravnavali smo torej tri faktorje, ključne za našo raziskavo. Izločene faktorje prikazuje slika 1, ki poudarjeno kaže, kaj nas je zanimalo v raziskavi in kaj je predmet nadaljnjih analiz.

Smiselnost uporabe faktorske analize smo preizkusili z Bartlettovim testom sferičnosti $(\mathrm{BT}=759,61)$, katerega velika statistična zanesljivost kaže na to, da je izločene faktorje mogoče interpretirati (Fulgosi, 1984). Velika vrednost tega statističnega podatka potrjuje smiselnost uporabe te metode (Bastič, 2006). Poleg Barlettovega testa sferičnosti smo uporabili Keiser-Meyer-Olkinovo statistiko $(\mathrm{KMO}=0,563)$. Uporaba faktorske analize je smiselna pri veliki vrednosti tega statističnega podatka, to je pri vrednosti, ki je večja od 0,5 (Bastič, 2006). Zanesljivost vprašalnika smo preverili z alfa koeficientom notranje skladnosti, gre za t. i. Cronbachov koeficient zanesljivosti alfa. Koeficient zavzema vrednosti med 0 in 1 , zanesljivost pa je sprejemljiva, če koeficient preseže vrednost 0,60 (Bastič, 2006). Koeficient za celoten vprašalnik kaže vrednost 0,603. Cronbachov koeficient notranje skladnosti kaže za prvi izločeni faktor socialne infrastrukture (soseska) vrednost 0,643 , za drugi izločeni faktor $\mathrm{v}$ socialni infrastrukturi (grajeno okolje) pa vrednost 0,663.

Druga faza je bila osrednja raziskava prečnega tipa. Uporabili smo izdelan vprašalnik iz pilotske študije. Zaradi tega smo pri zbiranju podatkov uporabili metodo snežne kepe (Lobe, 2006). Pri uporabi te vrste vzorčenja se za oblikovanje vzorca proučevane skupine uporabljajo osebna poznanstva. Izbere se manjši vzorec oseb, ki odgovarjajo na vprašalnik, obenem pa k izpolnjevanju povabijo svoje znance (Klinc idr., 2010). Vsak naslednji anketiranec naj bi zagotovil nekaj novih anketirancev. Prednost tega vzorčenja je predvsem $\mathrm{v}$ hitrem dopolnjevanju vzorca, ki pa je odvisen samo od začetne izbire populacije. To je obenem tudi slabost, saj po začetni izbiri vzorca nad njim nimamo več nadzora. V anketi je sodelovalo 729 udeležencev. Od teh je bilo 250 udeležencev mlajših od 35 let (34,29\%), 362 jih je bilo starih med 35 in 65 let $(49,66 \%), 117$ udeležencev pa je bilo starejših od 65 let (16,05\%). Med temi je bilo 12 udeležencev brezposelnih (1,65\%), 188 je bilo študentov (25,79\%), 431 zaposlenih (59,12 \%), 98 pa upokojenih $(13,4 \%)$. Po spolu so bili udeleženci raziskave zastopani precej enakomerno: sodelovalo je 376 žensk (51,60 \%) in 353 moških (48,40\%). Zanimalo nas je, katere so statistično značilne razlike glede na starost udeležencev, ki se navezujejo na sosesko, in katere so tiste, ki se navezujejo na grajeno okolje, kar skupaj razumemo kot grajeno socialno infrastrukturo.

\section{Rezultati in interpretacija}

Glede na zaznano močno korelacijo med starostjo in statusom zaposlenost (Pearsonov korelacijski koeficient $r=0,57$ ) smo podatke naprej analizirali z multivariatno analizo variance (MANOVA), in sicer glede na starost in zaposlenost (glej preglednico 1). Tako smo preverili, ali tovrstna analiza kaže drugačne statistično značilne razlike opazovanih spremenljivk, kot jih v nadaljevanju kaže enosmerna analiza variance (ANOVA), kar bi lahko pomenilo, da zaposlitev pomembno vpliva na rezultate.

Statistično značilne razlike $(p<0,01)$ glede na starost in status zaposlitve se kažejo glede pomembnosti razvitosti infrastrukture, vezane na prisotnost policijskih postaj, gasilcev, varnostnih 
Preglednica 2: Prikaz rezultatov enosmerne analize variance glede na starost udeležencev in grajeno socialno infrastrukturo

\begin{tabular}{lllllll}
\hline Spremenljivke & & Vsota kvadratov & df & Srednji kvadr. & F & P \\
\hline Infrastruktura (policija, gasilci ...) & $*$ & 7,374 & 2 & 3,687 & 2,975 & 0,050 \\
\hline Zadovoljstvo z nepremičnino & $* *$ & 14,163 & 2 & 7,081 & 6,805 & 0,001 \\
\hline Družbeno-ekonomska homogenost & $* *$ & 9,514 & 2 & 4,757 & 7,017 & 0,001 \\
\hline Medsosedski odnosi & $* * *$ & 11,23 & 2 & 5,615 & 7,946 & 0,000 \\
\hline Pogostost kriminalitete & & 0,126 & 2 & 0,063 & 0,020 & 0,980 \\
\hline Splošni občutek strahu & & 0,898 & 2 & 0,449 & 0,261 & 0,770 \\
\hline Medsebojna pomoč & & 3,617 & 2 & 1,809 & 2,366 & 0,095 \\
\hline Razvitost grajenega okolja & $*$ & 9,192 & 2 & 4,596 & 4,193 & 0,015 \\
\hline Vzdrževanje grajenega okolja & $* * *$ & 12,694 & 2 & 6,347 & 8,025 & 0,000 \\
\hline
\end{tabular}

* Razlika je statistično značilna $(p<0,05)$.

** Razlika je statistično značilna $(p<0,01)$.

*** Razlika je statistično značilna $(p<0,001)$.

služb ipd., glede družbeno-ekonomske homogenosti soseske, medsosedskih odnosov, pogostosti pojava kriminalitete (vlomi, ropanje, vandalizem, fizični in besedni napadi) in glede razvitosti grajenega okolja. Rezultati kažejo, da se statistično značilne razlike med opazovanima faktorjema kažejo enakovredno, in sicer tako v okviru prvega faktorja (soseska) kot v okviru drugega faktorja (grajeno okolje) po dva značilna dejavnika. Podatke smo analizirali še z enosmerno analizo variance (ANOVA) glede na starost, kar smo prikazali $\mathrm{v}$ preglednici 2.

Statistično značilne razlike $(\mathrm{p}<0,01)$ glede na starost in splošne značilnosti grajenega okolja se kažejo glede pomembnosti razvitosti infrastrukture, vezane na prisotnost policijskih postaj, gasilcev, varnostnih služb ipd., glede na zadovoljstvo z nepremičnino, družbeno-ekonomske homogenosti soseske, medsosedskih odnosov ter razvitosti in vzdrževanja grajenega okolja. Rezultati kažejo, da se statistično značilne razlike med opazovanima faktorjema izkazujejo neenakovredno. V okviru prvega faktorja (soseska) se izkazujejo štirje dejavniki, v okviru drugega faktorja (grajeno okolje) pa le dva značilna dejavnika.

Preglednica 3 izkazuje povprečne vrednosti strinjanja udeležencev glede na statistično značilne razlike, izkazane v preglednicah 1 in 2. Rezultati kažejo, da se statistično značilne razlike med opazovanima faktorjema izkazujejo dokaj enakovredno. Glede na navedeno menimo, da zaposlitev ne vpliva pomembno na iskane rezultate, čeprav s starostjo korelira. V okviru prvega faktorja (soseska) se tako izkazujejo štirje dejavniki, v okviru drugega faktorja (grajeno okolje) pa trije značilni dejavniki. Statistično značilne razlike v okviru opazovanih faktorjev (soseska in grajeno okolje) torej kažejo, da je izmed faktorjev, ki jih izloča faktorska analiza, najpomembnejši faktor soseska, $\mathrm{v}$ okviru katerega se statistično značilne razlike kažejo pri večini opazovanih dejavnikov.
Glede na bližino infrastrukture (policija, gasilci, varnostne službe) izkazujejo najmlajši udeleženci raziskave precej višjo stopnjo strinjanja kot starejši udeleženci raziskave $(M=3,423)$, kar pomeni, da starejši menijo, da je po njihovem zaznavanju tovrstna infrastruktura dlje od njihovega bivališča, kot to zaznavajo mlajši udeleženci raziskave. Glede na zadovoljstvo z nepremičnino, v kateri udeleženci raziskave trenutno bivajo, izkazujejo starejši precej višjo stopnjo strinjanja kot mlajši udeleženci raziskave $(\mathrm{M}=4,058)$. Glede občutka, da je soseska, v kateri udeleženci raziskave bivajo, družbeno-ekonomsko homogena in posledično stabilna, izkazujejo starejši udeleženci raziskave precej višjo stopnjo strinjanja kot mlajši $(M=3,758)$. Starejši udeleženci raziskave izkazujejo precej višjo stopnjo strinjanja tudi glede dobrih medsosedskih odnosov $(\mathrm{M}=3,717)$. Rezultati torej kažejo, da starejši udeleženci raziskave izražajo visoko stopnjo zadovoljstva $s$ svojim bivalnim okoljem. Pomen tega ugotavlja tudi Ramovš (2000), saj da so medčloveški odnosi enako pomembni kot materialna varnost. Kobal Grumova in Grum (2018) menita, da izključenost iz socialnega okolja povzroči osamljenost, izoliranost, občutek negotovosti in izgubo smisla življenja, zato je podpora starejšemu pri vključevanju v družbeno okolje izjemno pomembna. Rezultate delno pojasnjujemo z ugotovitvami Filipoviča, ki je s sodelavci za Slovenijo ugotovil, da pomen sosedov pri vseh vrstah opore s starostjo anketirancev narašča (Filipovič Hrast idr., 2005). Zanimivo pa je, da starejši udeleženci raziskave glede kriminalitete v soseski izražajo višjo stopnjo strinjanja z vlomi in ropanjem (krajo torbic, denarnic npr. na avtobusih) $(M=3,717)$, mlajši udeleženci raziskave v soseski izražajo višjo stopnjo strinjanja glede vandalizma ter fizičnih in besednih napadov $(M=2,988)$. Navedeno lahko pojasnimo z ugotovitvami Meška in drugih (Meško idr., 2012), da se kriminalitete najmanj bojijo mlajši, čeprav so prav ti najpogosteje viktimizirani. Občutek pripadnosti neki skupnosti lahko pomaga, da ljudje bolj zaupajo svojim sposobnostim, s tem pa se ošibi občutek za nevarnost viktimizacije in se zmanjša strah (Meško idr., 2012). 
Preglednica 3: Povprečne vrednosti strinjanja udeležencev glede na zadovoljstvo udeležencev z nepremičnino, v kateri bivajo, in starost udeležencev raziskave

\begin{tabular}{|c|c|c|c|c|c|c|c|}
\hline \multicolumn{2}{|l|}{ Dejavniki } & \multirow{2}{*}{$\begin{array}{l}\text { Število } \\
\text { udeležencev }\end{array}$} & \multirow[t]{2}{*}{ Povprečje } & \multirow[t]{2}{*}{ Std. deviacija } & \multirow{2}{*}{$\begin{array}{l}\begin{array}{l}\text { Std. napaka } \\
\text { povprečja }\end{array} \\
\text { Spodnja meja }\end{array}$} & \multicolumn{2}{|c|}{ Interval zaupanja za povprečje } \\
\hline & & & & & & Zgorn & \\
\hline \multirow{3}{*}{ Infrastruktura (policija, gasilci ...) } & 1 & 258 & 3,423 & 1,038 & 0,065 & 3,295 & 0,360 \\
\hline & 2 & 376 & 2,926 & 1,155 & 0,060 & 2,808 & 3,043 \\
\hline & 3 & 89 & 3,098 & 1,247 & 0,131 & 2,625 & 3,150 \\
\hline \multirow{3}{*}{ Zadovoljstvo z nepremičnino } & 1 & 260 & 3,842 & 0,889 & 0,055 & 3,734 & 3,951 \\
\hline & 2 & 380 & 3,918 & 1,107 & 0,057 & 3,807 & 4,030 \\
\hline & 3 & 85 & 4,059 & 1,062 & 0,115 & 3,830 & 4,288 \\
\hline \multirow{3}{*}{$\begin{array}{l}\text { Družbeno-ekonomska homoge- } \\
\text { nost }\end{array}$} & 1 & 258 & 3,636 & 0,778 & 0,048 & 3,540 & 3,731 \\
\hline & 2 & 378 & 3,661 & 0,863 & 0,044 & 3,574 & 3,749 \\
\hline & 3 & 87 & 3,759 & 0,876 & 0,094 & 3,572 & 3,945 \\
\hline \multirow{3}{*}{ Medsosedski odnosi } & 1 & 260 & 3,592 & 0,898 & 0,056 & 3,483 & 3,702 \\
\hline & 2 & 380 & 3,663 & 0,833 & 0,043 & 3,579 & 3,747 \\
\hline & 3 & 85 & 3,718 & 0,781 & 0,085 & 3,549 & 3,886 \\
\hline \multirow{3}{*}{ Pogostost kriminalitete } & 1 & 260 & 2,988 & 1,671 & 0,104 & 2,784 & 3,192 \\
\hline & 2 & 378 & 2,854 & 1,883 & 0,097 & 2,664 & 3,045 \\
\hline & 3 & 87 & 2,241 & 1,635 & 0,175 & 1,893 & 2,590 \\
\hline \multirow{3}{*}{ Razvitost grajenega okolja } & 1 & 258 & 3,372 & 1,044 & 0,065 & 3,244 & 3,500 \\
\hline & 2 & 380 & 3,258 & 1,081 & 0,055 & 3,149 & 3,367 \\
\hline & 3 & 87 & 3,299 & 0,966 & 0,104 & 3,093 & 3,505 \\
\hline \multirow{3}{*}{ Vzdrževanje grajenega okolja } & 1 & 258 & 3,457 & 0,851 & 0,053 & 3,353 & 3,562 \\
\hline & 2 & 378 & 3,402 & 0,914 & 0,047 & 3,310 & 3,495 \\
\hline & 3 & 87 & 3,586 & 0,909 & 0,097 & 3,392 & 3,780 \\
\hline
\end{tabular}

Opomba: 1 (starost do 35 let), 2 (starost do 65 let), 3 (starost več kot 65 let).

Zanimivo je tudi, da glede razvitosti grajenega okolja (objekti, parkirišča, parki, sprehajalne poti ipd.) najvišjo stopnjo strinjanja izkazujejo mlajši udeleženci raziskave $(\mathrm{M}=3,372)$, sledijo jim starejši $(M=3,298)$, udeleženci raziskave, ki spadajo v srednjo starostno skupino, pa izražajo najnižjo stopnjo strinjanja $(M=3,257)$, kar pomeni, da je prav ta starostna skupina najmanj zadovoljna z razvitim grajenim okoljem. Navedeno si razlagamo z rezultati raziskave Terčka (2005), ki je podrobneje analiziral dejavnike, kot so: starost, kakovost stavb in stanovanja, medsosedski odnosi in prihodnje preference anketirancev. V zvezi z nezadovoljstvom z bivalnim okoljem ugotavlja, da je na prvem mestu težava s parkirišči $(60,2 \%$ anketirancev je nezadovoljnih), visoko pa je izraženo zadovoljstvo z varnostjo v soseski (52,7 \%) in z medsosedskimi odnosi (56,9\%). Prav parkirišča so verjetno precej bolj zanimiva za aktivno, srednjo starostno skupino kot starejšo generacijo, ki je dnevno precej manj mobilna. Glede vzdrževanja grajenega okolja (ruševine, temni in neosvetljeni prehodi in sprehajalne poti, nevzdrže- vani parki, podrta drevesa ipd.) izkazujejo starejši udeleženci raziskave precej višjo stopnjo strinjanja kot mlajši udeleženci raziskave $(\mathrm{M}=3,586)$, kar nas preseneča. Pričakovali smo, da bodo starejši izražali precej nižjo stopnjo strinjanja, predvsem glede vzdrževanja grajenega okolja. Vendar rezultati kažejo, da so v splošnem starejši ( $v$ primerjavi z mlajšsimi udeleženci raziskave) precej bolj zadovoljni, tako z značilnostmi bivalne skupnosti kot z dejanskimi značilnostmi grajenega okolja.

Rezultate si razlagamo z ugotovitvami številnih raziskovalcev, da starejši ljudje še vedno na splošno raje ostarijo v svojem domu, tj. v znanem okolju, ki ga sprejemajo tako, kot je, saj se pogosto bojiijo, da bi zanje prehod v kolektivno ali institucionalno življenjsko okolje neizogibno pomenil izgubo neodvisnosti. Grum in Kobal Grumova (2018) poudarjata, da so sosedska omrežja pomemben del osebnih omrežij. Tako je mogoče sklepati, da je za zadovoljstvo z nepremičnino ali z bivalnimi dejavniki, v katere je vpeta potencialna nepremičnina 
ali bivalno okolje (soseska), potrebno tudi optimalno subjektivno čustveno blagostanje. Hkrati je mogoče zbrane rezultate primerjati tudi z rezultati proučevanj razmeroma novega pojava na področju psiholoških dejavnikov, vezanih na nepremičnino, in sicer navezanosti na nepremičnino (Khozaei idr., 2012). Navezanost, ki je v psihologiji že znan in dokaj raziskan pojav (Howe, 2011), tako dobiva skozi poti raziskovanja odnosa uporabnikov do nepremičnin novo razsežnost. Zdi se namreč, da osebe, ki jim je pomembno, v kakšnem infrastrukturnem okolju živijo ali bi želele živeti, izražajo konstruktivno navezanost na nepremičnino tudi z višjim subjektivno čustvenim blagostanjem (Florek, 2011). Taka spoznanja lahko ključno vplivajo na ustvarjanje uspešne medgeneracijske stanovanjske politike. Staranje prebivalstva se ne zdi proces, ki bi ga morale družbe preprečiti, temveč proces, ki ga je treba razumeti kot rezultat in posledico načrtovanih ali želenih procesov in ki zahteva prilagoditev socialnih institucij in storitev (Kerbler, 2011). Dobri prostorski odnosi sledijo kakovostnemu bivalnemu okolju le tedaj, kadar omogočajo tudi uresničevanje kar največ potreb prebivalcev (Zapušek in Kučan, 2009). Ti interesi in potrebe pa se spreminjajo glede na starost in socialni položaj $\mathrm{v}$ družbi.

\section{Sklep}

Posamezni tipi sosesk, ki izhajajo iz njihovih značilnosti, lahko med uporabniki izražajo različne probleme. Pri tem pa, kot navaja Adriaansova (2007), lokacija soseske niti ni tako pomembna, kot sta pomembna dojemanje uporabnikov in njihova raba prostora, pri čemer so poglavitne tri spremenljivke: starost uporabnikov, značilnosti bivalne skupnosti in dejanske značilnosti grajenega okolja. Prav zato nas je v raziskavi zanimalo, ali se kažejo statistično značilne razlike glede na starost udeležencev, značilnosti bivalne skupnosti (splošno zadovoljstvo, družbeno-ekonomska homogenost, medsosedski odnosi, stopnja kriminalitete, občutek strahu in nelagodja, medsosedska pomoč) in glede na grajeno okolje (razvitost, vzdrževanje in čistoča grajenega okolja). Zanimalo nas je, ali morebitne statistično značilne razlike, ki jih prepoznavajo udeleženci, lahko kažejo na medgeneracijsko različno dojemanje bivalnega okolja ali, gledano širše, dojemanje grajene socialne infrastrukture, $v$ kateri živijo.

Rezultati v naši raziskavi kažejo, da so v splošnem starejši bolj zadovoljni tako z značilnostmi bivalne skupnosti kot z značilnostmi grajenega okolja in njegovim vzdrževanjem. Rezultate si razlagamo z ugotovitvami številnih raziskovalcev, da starejši ljudje še vedno na splošno raje ostarijo v svojem domu. $\mathrm{V}$ tem kontekstu nekritično branijo svoje bivalno okolje, ne glede na njegove pomanjkljivosti, saj se zaradi svoje ekonomske neudeleženosti v družbi (upokojeni, omejeni z dohodki) ne čutijo več družbeno aktivni, da bi lahko pomembno vlivali na odpravo teh pomanjkljivosti. Zanimive so tudi ugotovitve Paina (2000), da raziskovalci v zadnjem času na starost vse bolj gledajo kot na kulturno, ne več kronološko kategorijo, kar pomeni, da dajejo poudarek posebnosti okoliščin in načinu življenja ljudi v različnih življenjskih obdobjih.

Rezultati kažejo na številne statistično pomembne razlike glede na starost udeležencev raziskave (medgeneracijski razkoraki). Statistično značilne razlike v okviru opazovanih faktorjev (soseska in grajeno okolje) kažejo, da je izmed vseh faktorjev, ki jih izloča faktorska analiza, najpomembnejši faktor soseska, v okviru katerega se statistično značilne razlike kažejo pri večini opazovanih dejavnikov. Ugotavljamo, da ima bivalno okolje velik učinek na zadovoljstvo in dobro počutje prebivalcev, in kot mnogi drugi avtorji (Adriaanse, 2007; Kobal Grum in Grum, 2018) sklepamo, da urbanisti in oblikovalci prostora večinoma niso naredili presežka pri oblikovanju okolja v stanovanjskih soseskah, v katerih naj bi ljudje medgeneracijsko živeli udobno in uživali kar največjo kakovost bivalne socialne infrastrukture, in to ne glede na starostne razlike. Kot ugotavlja Sendi (2005), sodobni časi zahtevajo sodobne poglede na načrtovanje stanovanjskih območij. Načini načrtovanja, $\mathrm{v}$ katerih mnenja in želje obstoječih ali potencialnih stanovalcev niso upoštevani, niso več sprejemljivi, ne delujejo več in ne vodijo več $\mathrm{v}$ najboljšo rabo zemljišča. Tako za prostorsko načrtovanje, pri čemer je še vedno osrednje vprašanje, kako zagotoviti ustrezno namensko rabo površin, ki bo v sozvočju $s$ cilji in usmeritvami družbenega razvoja in pri čemer vsi akterji nastopajo kot enakovredni partnerji (Ravbar, 2007), kot za načrtovanje stanovanjskih območij ostaja osrednje vprašanje, kako izkoristiti stanovanjsko namensko rabo zemljišča tako, da bo dosežena najboljša raba zemljišča. Pri tem to rabo lahko razumemo kot razširjeno opredelitev najgospodarnejše rabe zemljišča, tudi primerno podprte $s$ pričakovanji, željami, hotenji ljudi in podobno. Opažanja so pomembna predvsem za ocenjevanje kakovosti življenja, ki je danes v svetu eden prevladujočih konceptov in je le stežka doumljiv brez razumevanja kakovosti urbanega okolja. Menimo, da bi bilo treba v nadaljnjih raziskavah še izboljšati kakovost merskih instrumentov $\mathrm{v}$ smislu uporabe obstoječih tujih vprašalnikov. Glede na navedeno tudi menimo, da je razumevanje opazovanih razlik glede na demografske značilnosti uporabnikov prostora ključno pri oblikovanju trajnostne stanovanjske politike.

\section{Bojan Grum}

Nova univerza, Evropska pravna fakulteta, Ljubljana, Slovenija e-naslov: bgrum@siol.net 


\section{Viri in literatura}

Adriaanse, C. C. M. (2007): Measuring residential satisfaction: a residential environmental satisfaction scale (RESS). Journal Housing Built Environment, 22, str. 287-304. DOI: 10.1007/s10901-007-9082-9

Balfour, J. L., in Kaplan, G. J. (2002): Neighborhood environment and loss of physical function in older adults: Evidence from the Alameda county study. American Journal of Epidemiology, 155(6), str. 507-515. DOI: 10.1093/aje/155.6.507

Bastič, M. (2006): Metode raziskovanja. Maribor, Univerza v Mariboru, Ekonomsko poslovna fakulteta Maribor.

Baumeister, R. F., in Leary, M. R. (1995): The need to belong: Desire for interpersonal attachments as a fundamental human motivation. Psychological Bulletin, 117(3), str. 497-529. DOI: 10.1037//00332909.117.3.497

Costa-Font, J., Mascarilla-Miró, O., in Elvira, D. (2009): Ageing in place? An examination of elderly people housing preferences in Spain. Urban studies, 46(2), str. 295-316. DOI: 10.1177/0042098008099356

Engle, M., in Altschuld, J. W. (2014): Needs assessment: The perspective from the public sector. V: Altschuld, J. W., in R. Watkins (ur.): Needs assessment: Trends and a view toward the future. New directions for evaluation, str. 33-45. Hoboken, NJ, Wiley. DOI: 10.1002/ev.20101

Erdogan, N., Akyol, A., Ataman, B., in Domkeci, V. (2008): Comparison of urban housing satisfaction in modern and traditional neighborhoods in Edirne, Turkey. Social Indicators Research, 81(1), str. 127-148. DOI: $10.1007 / \mathrm{s} 11205-006-0018-7$

Ferguson, K. M., in Mindel, C. H. (2007): Modeling fear of crime in Dallas neighborhoods: A test of social capital theory. Crime Delinquency, 53(2), str. 658-679. DOI: 10.1177/0011128705285039

Filipovič Hrast, M., Kogovšek, T., in Hlebec, V. (2005): Starostniki in njihova vpetost v sosedska omrežja. Družboslovne razprave, 49/50, str. 205-221.

Florek, M. (2011): No place like home: Perspectives on place attachment and impacts on city management. Journal of Town \& City Management, 1(4), str. 346-354.

Frolova, E. V., Vinichenko, M. V., Kirillov, A. V., Rogach, O. V., in Kabanova, E. E. (2016): Development of social infrastructure in the management practice of local authorities: Rends and factors. International Journal of Environmental \& Science Education, 11(15), str. 7421-7430.

Fulgosi, A. (1984): Faktorska analiza. Zagreb, Filozofski fakultet v Zagrebu.

Gallagher, N. A., Gretebeck, K. A, Robinson, J. C, Torres, E. R., Murphy, S. L., in Martyn, K. K. (2010): Neighborhood factors relevant for walking in older, urban, African American adults. Journal of Aging and Physical Activity, 18(1), str. 99-115. DOI: 10.1123/japa.18.1.99

Greenwald, M., Barrett, L. L., Ginzler, E., Copeland, A., Kochera, A., Straight, A. (2003): These four walls. Americans 45+ talk about home and community. Dostopno na: http://assets.aarp.org/rgcenter/il/four_walls. pdf (sneto 20. 10. 2018).

Grum, B. (2017): Impact of facilities maintenance on user satisfaction. Facilities, 35(7-8), str. 405-421. DOI: 10.1108/f-03-2016-0034

Grum, B., in Kobal Grum, D. (2015): A model of real estate and psychological factors in decision-making to buy real estate. Urbani izziv, 26(1) str. 82-91. DOI: 10.5379/urbani-izziv-en-2015-26-01-002

Grum, B., in Temeljotov Salaj, A. (2011): Vloga lastnih in zunanjih dejavnikov pri konstrukciji vprašalnika za merjenje pričakovanj potencialnih pridobiteljev nepremičninskih pravic. Anthropos, 43 (1-2), str. 257-275. DOI: 10.5379/urbani-izziv-2010-21-02-004
Grum, B., in Temeljotov Salaj, A. (2013): The comparison of expressed satisfaction and expectations of potential real estate buyers in Slovenia and Japan. Facilities, 31(1-2), str. 6-23. DOI: 10.1108/02632771311292482

Harper, L., in Bayer, A. H. (2000): Fixing to stay: A national survey of housing and home modification issues. Washington, DC, AARP.

Howe, D. (2011): Attachment across the lifecourse. London, Palgrave.

Imamoglu, C. (2007): Assisted living as a new place schema. A comparison with homes and nursing homes. Environment and Behavior, 39, str. 246-268. DOI: 10.1177/0013916506289977

Kemp, C. L., Ball, M. M., Hollingsworth, C., in Perkins, M. M. (2012): Strangers and friends: residents' social careers in assisted living. Psychological Sciences and Social Sciences, 67, str. 491-502. DOI: 10.1093/ geronb/gbs043

Kerbler, B. (2011): Prilagajanje grajenega bivalnega okolja za potrebe starejših ljudi. Geodetski vestnik, 55(1), str. 57-69. DOI: 10.15292/ geodetski-vestnik.2011.01.057-069

Khozaei, F., Ramayah, T., Hassan, A. S., in Surienty, L. (2012): Sense of attachment to place and fulfilled preferences, the mediating role of housing satisfaction. Property Management, 30(3), str. 292-310. DOI: 10.1108/02637471211233945

Klinc, R., Turk, Ž., in Dolenc, M. (2010): Raziskava o rabi informacijskokomunikacijskih tehnologij v Slovenski gradbeni industriji. Gradbeni vestnik, 59, str. 269-276.

Kobal Grum, D., in Grum, B. (2018): The association between pro-environmental behaviour nad subjective well-being. V: Grum, B. (ur.): Book of proceedings, 3rd Conference of Interdisciplinary Research on Real Estate, (CIRRE), str. 43-53. Ljubljana, Institute of Real Estate Studies. DOI: 10.5379/urbani-izziv-en-2015-26-01-002

Kulbickienè, L. (2004): Lietuvos gyventoju kultūriniai poreikiai: kultūros istaigu vertinimas ir lankymas. Sociologija. Mintis ir veiksmas, 8(2), str. 64-71.

Lobe, B. (2006): Mixing qualitative and quantitative methods in the environment of new information-communication technologies. Ljubljana, Univerza v Ljubljani, Fakulteta za družbene vede.

Mendes De Leon, C. F., Cagney, K. A., Bienias, J. L., Barnes, L. L., Skarupski, K. A., Scherr, P. A., idr. (2009): Neighborhood social cohesion and disorder in relation to walking in community-dwelling older adults: A multilevel analysis. Journal of Aging and Health, 21(1), str. 155-171. DOI: $10.1177 / 0898264308328650$

Meško, G. (2001): Kriminalna prevencija z načrtovanjem in oblikovanjem okolja. Socialna pedagogika, 5(4), str. 445-468.

Meško, G., Šifrer, J., in Vošnjak, L. (2012): Strah pred kriminaliteto v mestih in vaških okoljih v Sloveniji. Varstvoslovje, 14(3), str. 259-276.

Miloševič Arnold, V. (2003): Komunikacija med zaposlenimi in svojci stanovalcev socialnih domov. V: Zbornik predavanj. 14. strokovno srečanje Zveze društev medicinskih sester in zdravstvenih tehnikov Slovenije, Terme Zreče, 21. in 22. oktober 2003 (str. 43-49). Zreče, Zbornica zdravstvene nege Slovenije - Zveza društev medicinskih sester in zdravstvenih tehnikov Slovenije.

Missimer, M., Robert, K. H., in Broman, G. (2017): A strategic approach to social sustainability - Part 1: exploring social system. Journal of Cleaner Production, 140, str. 32-41. DOI: 10.1016/j.jclepro.2016.03.170

Mohit, M. A., Ibrahim, M., in Rashid, Y. R. (2010): Assessment of Residential Satisfaction in Newly Designed Public Low-Cost Housing in Kuala Lumpur, Malaysia. Habitat International, 34(1), str. 18-27. DOI: 10.1016/j. habitatint.2009.04.002 
Newman, O. (1972): Defensive space. New York, Macmillan.

Pain, R. (2000): Place, social relations and the fear of crime: A review. Progress in Human Geography, 24(3), str. 365-387. DOI: 10.1191/030913200701540474

Parry, J., Vegeris, S., Hudson, M., Barnes, H., in Taylor, R. (2004): Independent living in later life. Research Report No 216. Dostopno na: http:// campaigns.dwp.gov.uk/asd/asd5/rports2003-2004/rrep216.pdf (sneto 5. 9. 2017).

Popov, Y. (2017): Relations between wellbeing and transport infrastructure of the country. Procedia Engineering, 178. str. 579-588. DOI: 10.1016/j.proeng.2017.01.112

Ramovš, J. (2000): Medgeneracijska povezanost, samopomoč in kakovostna starost. Socialno delo, 39(4-5), str. 315-329.

Ravbar, M. (2007). Prostorsko planiranje - čemu? Geodetski vestnik, 51(2), str. 233-245.

Roy, N., Bube, R., Despres, C., Freitas, A., in Legare, F. (2018): Choosing between staying at home or moving: A systematic review of factors influencing housing decisions among frail older adults. PLoS One, 13(1). DOI: 10.1371/journal.pone.0189266

Rojo, P., Fernandez-Mayoralas, G., Pozo Rivera, E., in Manuel Rojo, A. (2001): Ageing in place: Predictors of the residential satisfaction of elderly. Social Indicators Research, 54(2), str. 173-208. DOI: 10.1023/a:1010852607362

Sabia, J. (2008): There's no place like home: A hazard model analysis of aging in place among older homeowners in the PSID. Research on Aging, 30(1), str. 3-35. DOI: 10.1177/0164027507307919

Sam, M., Fauzi, M., in Saadatian, O. (2012): Residential satisfaction and construction. Journal of Scientific Research and Essays, 7(15), str. 15561563.

Secker, J., Hill, R., Villeneau, L., in Parkman, S. (2003): Promoting independence: But promoting what and how? Ageing and Society, 23, str. 375-391. DOI: 10.1017/s0144686x03001193

Sendi, R. (2005): Sodelovanje stanovalcev kot pogoj za uspešno izvedbo prenove stanovanjskih sosesk. Urbani izziv, 16(2), str. 5-15. DOI: 10.5379/urbani-izziv-2005-16-02-001

Sierra, L., Yepes, V., in Pellicer, E. (2017): Assessing the social sustainability contribution of an infrastructure project under conditions of uncertainty. Environmental Impact Assessment Review, 67, str. 61-72. DOI: 10.1016/j.eiar.2017.08.003

Sierra, L., Yepes, V., in Pellicer, E. (2018): A review of multi-criteria assessment of the social sustainability of infrastructures. Journal of Cleaner Production, str. 496-513. DOI: 10.1016/j.jclepro.2018.03.022

Sirgy, M. J., in Cornwell, T. (2002): How neighborhood features affect quality of life. Social Indicators Research, 59, str. 79-114.

Smrke U., Blenkuš, M., Sočan, G. (2018): Vprašalniki zadovoljstva z bivalnim okoljem: sistematični pregled. Urbani izziv, 29(2), str. 7-21. DOI: 10.5379/urbani-izziv-2018-29-02-001

Strath, S., Isaacs, R., in Greenwald, M. J. (2007): Operationalizing environmental indicators for physical activity in older adults. Journal of Aging and Physical Activity, 15(4), str. 412-424. DOI: 10.1123/japa.15.4.412

Temeljotov Salaj, A., in Petrič, G. (2009): Nepremičninski dejavniki organizacijske klime. V: Brezovec, A. Mekinc, J. (ur.): Management, izobraževanje in turizem: kreativno $v$ spremembe; Zbornik referatov, str. $2870-$ 2879. Portorož, Turistica,.

Theodori, G. L. (2001): Examining the effects of community satisfaction and attachment on individual wel-being. Rural Sociology, 66(4), str. 618-628. DOI: 10.1111/j.1549-0831.2001.tb00087.x
Trček, F. (2005): Sociološka anketna raziskava, Prenova stanovanjskih sosesk v Ljubljani -Savsko naselje. Urbani izziv, 2005, 16(2), str. 24-35. DOI: 10.5379/urbani-izziv-2005-16-02-003

Uršič, M. (2005): Spreminjanje bivalne kakovosti in stanovanjska mobilnost v Ljubljani, Naraščanje socialne nestabilnosti v večjih stanovanjskih soseskah? Urbani izziv, 16(2), 36-47. DOI: 10.5379/urbani-izziv-2005-16-02-004

Vaznonienè, G. (2015): The role of rural community enhancing rural social infrastructure changes. Research for rural development, 2, str. 176182. DOI: 10.1515/euco-2017-0031

Vaznonienè, G., in Pakeltienė, R. (2017): Methods for the assessment of rural social infrastructure needs. European Countryside, 9(3), str. 526540.

Zapušek, A., in Kučan, A. (2009): Stanovanjske krajine in kakovost bivanja. Predstavitev ukrepov za izboljšanje bivalne kakovosti, Annales, 19(1), str. 1-18.

Weber, B., Alfen, H. W., in Staub-Bisang, M. (2016): Infrastructure as an Asset Class-Investment strategy, Sustainability, Project finance and PPP. Hoboken, NJ, John Wiley \& Sons. DOI: 10.1002/9781119226574

Wiles, J. L., Allen, R. E. S., Palmer, A. J., Hayman, K. J., Keeling, S., in Kerse, N. (2009): Older people and their social spaces: A study of well-being and attachment to place in Aotearoa New Zealand. Social Science \& Medicine, 68(4), str. 664-671. DOI: 10.1016/j.socscimed.2008.11.030

Wylde, M. A. (2008): The future of assisted living. Residents' perspectives, 2006-2026. V: Golant S. M. Hyde J. (ur.): The assisted living residence. A vision for the future, str. 169-197. Baltimore, MD, The Johns Hopkins University Press. 